\title{
Gender Analysis of Fish Production in Gambela Region, Ethiopia
}

\author{
Abebe Cheffo ${ }^{1}$, Yared Mesfin and Hiwot Teshome \\ Ethiopian Institute of Agricultural Research, National Fishery and aquatic life research center \\ P.O.Box 64, Sebeta, Ethiopia
}

\begin{abstract}
Women's access to and control over productive resources is highly constrained in most of the developing world. These constraints are usually overlooked. Gender analysis is very crucial to unpack the existing constraints and see the gap that affects technology transfer among men and women. The Objective of this study is to conduct gender analysis of capture fishery in selected woredas in Gambela region. The study was conducted in four purposively selected woredas of Anua Zone, Gambela region. Sample selection was done on household bases. Out of the 520 fisher households in the woredas, $10 \%$ of them are taken based on the minimum standard sample size requirements for social sciences. Among these, 190 were female (FHHHs) while 330 were male headed households (MHHHs). The determination of sample size is based on PPS to the size of the overall population engaged in fisheries. As a result, $19 \mathrm{FHHHs}$ and $33 \mathrm{MHHHs}$ were included in the research. Quantitative data was collected using structured questionnaire from 52 households. In addition, a focus group discussion was made to elicit more information on gender roles and relationships. The output of the study indicated that, men in MHHHs are entirely responsible for the fishing activity. In addition, women \& youth in MHHHs have a significant role in maintaining the daily harvest of fish. Women in FHHHs are traditionally represented for collecting, processing, cooking and selling the catch. Though decision on selling the catch is mainly carried out by men, women were also found to have a say. Despite women's involvement in value adding processes of capture fishery, a significant gap was observed between men and women headed households in accessing extension services. Thus, there is a significant difference in volume of fish harvested per fish type per day which was 10.5 and 7.5 kilograms per day for Male headed household and female headed household respectively. Daily fish catch of women headed household should be increased by offering improved fishing equipments.
\end{abstract}

Keywords: Gender analysis, MHHHs, FHHHs, Capture fishery, Gambella region

DOI: $10.7176 / \mathrm{JNSR} / 12-19-03$

Publication date:October $31^{\text {st }} 2021$

\section{INTRODUCTION}

\subsection{Background of the Study}

Gender is defined as a qualitative and independent character of men's and women's position in a society. The terms Gender and sex are distinct in that gender is socially constructed while sex is entirely biological. Gender relations are constituted in terms of relations of power and dominance that structures the life chances of men and women. Hence, it is rooted in the conditions of production and reproduction which is reinforced by the cultural, religious, and ideological systems prevailing in a society (Ostergaard, 1997; Fetenu, 1997).

Women are often engaged in gleaning and near-shore fishing (Vunisea, 1997) while men fish near-shore and off-shore. Gleaning for mollusks as an activity is almost invisible in most fisheries studies and statistics. Women also perform many unpaid pre and post-harvesting tasks(mending nets, collecting bait, preparing food for fishers, keeping accounts), which are unacknowledged or undercounted as employment (Williams et al., 2005; FAO, 2006, Choo,2005). However, women are outnumbering men in processing and trading fish across the world, although these "informal" activities might also not be enumerated and are invisible in the national statistics. In some societies they are considered to be more skilled at negotiating than men because they are subservient and refrain from engaging in conflict (Kusakabe et al., 2006). In others, women are perceived to be exploiting male fishers who are dependent on them for credit (Bennett et al., 2001). In many parts of Africa, women dominate local markets for fish and other agricultural commodities, and a relatively extensive literature has emerged on women fish traders (Overa, 1993; Walker, 2001; 2002; ICSF, 2002; Nakato, 2005; Vales, 2005).

Gender Analysis is the process of analyzing information in order to ensure that development benefits and resources are effectively and equitably targeted to both women and men. Gender analysis refers to the study of different roles, responsibilities, assets in the agency of men and women, including their differential access to, control over and use of natural, financial, social, political and infrastructural resources (FAO, 2003).”

It is also defined as the systematic gathering and examination of information on gender differences and social relations in order to identify understand or redress in equalities based on gender. Gender analysis is a valuable descriptive and diagnostic tool to development planners and crucial for gender mainstreaming efforts (Hazel and Sally, 2000). This is to successfully anticipate and avoid any negative impacts that development interventions may have on women or men and their gender relations. It involves all the processes of analysing the roles, responsibilities, as well as access and control over of resources and benefits. 
There are a number of tools and frameworks to gender analysis including the Gender Analysis Matrix (GAM), Moser Framework, Harvard Analytical Framework, Capacities and Vulnerabilities Analysis Framework, Women's Empowerment (Longwe), framework, and Social Relations Approach (Candida et al., 1999). But for this case a rapid appraisal method is used due to shortage of time.

The existence of gender gap in the agricultural sectors of many developing countries as many women face gender-specific constraints that reduce their productivity and limit their contributions to agricultural production, economic growth and the well-being of their families and communities.

The small-scale fisheries sector in developing countries employs 25-27 million people on a full-time and part-time basis, with 70 million people employed in post-harvest activities, and with women representing about half of the workforce (FAO, World Fish Center, World Bank, 2008). Though this is the case, their access to productive resources such as land, labour and capital; credit and extension services are severely constrained in much of the developing world. This has affected their adoption of modern agricultural inputs or technologies (FAO, 2011).

The concept "fishing" is mostly pictured as an occupation of men in dangerous seas but it normally misses the contribution and role of women, youth and children, these invisible groups, may in fact contribute more economically than the traditionally recognized fishers (Williams, M.J.,et al., 2004).

Gender roles in small scale fisheries are quite diverse. Women are often, involved in drying, smocking, cooking, collecting, transporting and selling the catch while men are engaged in doing the actual fishing activity, filleting, boat and gear maintenance and purchase. There are cases where both men and women play changing roles depending on the local norms, access and control resource, mobility, type of technology involved, the extent of commercialization, and the product involved. The belief that men do the actual fishing, with women's involvement in post-harvest processing and marketing activities, remains prevalent across most cultural, social, political and economic strata (World Bank, 2009).

The extent and ways that women are involved in the fisheries sector can be diverse and can differ to those of men (Harrison, 2001). These roles also vary across localities, regions, countries, cultures and social structure.

Gender analysis in fishing communities is at an infant stage and is mostly limited to the different occupational roles that men and women have according to gender. Technology transfer and support efforts are mostly concentrated around the male dominated marine based fish catching, ignoring the complementary activities of processing, packaging and preservation for which women are responsible. According to the reports of FAO on the state of World Fisheries and Aquaculture in 2016, women accounted for $19 \%$ of the world population in engaged in the sector in 2014 . Women are constantly had less probability than men to own land or livestock, adopt new technologies, access to credit, extension advice (FAO 2011).

\subsection{Statement of the Problem}

The issue of gender is core for the development of agriculture. The role of men and women in the agricultural arena is not the same everywhere. Women's role to agricultural development is generally accepted. As part of agriculture, gender issues are also important to be investigated in fisheries. There is a general trend as to what men and women do in case of small scale capture fisheries. Yet, these roles are often culturally specific and changing (World Bank, 2009).

There is an inherent claim in most crop and livestock agricultural systems that women's contribution for farm based productive activities is comparable to that of men with more workloads. In addition men are frequently said to make significant decisions which places women in their subordinate position. In addition, women's lower access to rural services such as extension, credit and training on their productive role has worsened the situation (Mahlet, 2005).

The condition of workload and gender roles on productive activities is not the same everywhere. The assignment of specific duties depends on the culture or type of activity in which men and women are involved. In fisheries women usually acquire dynamic roles depending on the social norms about resource access and control, mobility, type of technology involved, the extent of commercialization and the product involved (World Bank, 2009).

Gender disparities in fisheries and aquaculture can result in lower labor productivity within the sector and inefficient allocation of labor at household and national levels. Customary beliefs, norms and laws, and/or unfavorable regulatory structures of the state, reduce women's access to fisheries resources and assets (FAO, 2006; Porter, 2006; Okali and Holvoet, 2007), confining them to the lower end of supply chains within the socalled "informal" sector in many developing countries. This implies that women are likely to constitute a larger proportion of the poor within this sector, as much as in agriculture, forestry and industry. Ecological degradation and depletion of aquatic resources have further constrained access to resources. These disparities are likely to be exacerbated by climate change. While women bear the brunt of the costs of gender inequities, these costs are distributed widely and are a cause of persistent poverty for all members of the society.

In Ethiopian case, the role of gender in small scale capture fisheries is so far not studied. The activity of 
small scale capture fishery is usually perceived masculine, overlooking the fact that women also have a significant role in value addition (ibid). Hence, the current study was proposed to elicit more evidence on this fact.

\subsection{Objective of the Study}

The general objective of this study is to conduct a gender analysis with regard to the employment of men and women in the capture fisheries sector. The specific objectives are:

$>$ To analyze the productive role of men and women household heads in capture fishery.

$>$ To assess women and men's access to rural services, their productive work load and status of decision making in capture fishery.

$>$ To analyze the differences in daily catches of fish between man headed and female headed household.

\section{METHODOLOGY}

\subsection{Location of the study area}

Gambela is one of the 9 regions and 2 administrative zones of Ethiopia. Administratively, the region consists of three zones namely Anywaa, Nuwer and Mejenger. It has 12 woredas and is located at $7^{0} 05^{\prime}$ to $8^{0} 17^{\prime} \mathrm{N}$ latitude and $33^{\circ} 00^{\prime}$ to $35^{\circ} 21^{\prime} \mathrm{E}$ longitudes in western Ethiopia. It shares boundaries with the South Sudan Republic in the west, with Sheka zone /SNNPR/ in the southeast, with Illubabor zone /Oromia Region/ in the north and east and with Benshangul-Gumuz in the North. The Region shows varied topographic features which influence its vegetation cover, soil type and climatic conditions. Altitude of the region ranges between 300-2300 m.a.s.1. It gently slopes to the west while its eastern part consisted of high plateau, mountain peaks and rocky land. The total areal coverage of Gambela region is $29,782.82 \mathrm{~km}^{2}(11,499.21 \mathrm{sq}$ miles). According the Ethiopian population census of 2009, the region has total population of 435,999 comprising 227,000 men and 208,999 women and is found 1,000 km away from capital city, Addis Ababa. It has an average annual rainfall of $800 \mathrm{~mm}-$ $1,200 \mathrm{~mm}$ with an annual temperature of $27.6^{0} \mathrm{c}$.

\subsection{Sampling Method and Sample Size}

The current study was conducted in three weredas of Agnewak Zone namely Abobo, Gog, Gambela town and one wereda called Itang special wereda. From each district /woreda/ one kebele was purposively selected for their high concentration in fishery activities. Out of the selected kebeles with a total of 520 farm households 190 were female and 330 were male headed (CSA, 2013). A random sample of 52 households was selected. This was done to meet the minimum sample size of $10 \%$ from the total population as constraints of budget and time were apparent by the time. Within the fixed sample size, PPS was applied based on number of male and female headed households in the population. The survey was distributed to a random sample of Abobo wereda 14 household, Gog wereda 12 household, Gambella town special woreda 12 household and Itang special wereda 14 households.

\subsection{Methods of Data Collection}

We followed two methods of data collocation by using structured questionnaire and arranging focus group discussion. We started data collection by using structured questionnaire based socioeconomic survey to obtain data on household composition by sex, age, formal years of schooling and religion as of May 2015. The data were collected from 4 weredas: Abobo, Gog, Gambella town special woreda and Itang special wereda.

In order to strengthen the findings of individual information from structured questionnaire, we arranged a focus group discussion in each wereda. Four interview sessions were conducted in the selected weredas. In Abobo, there was a group of people having 6 men and 4 women. In Gog, there were 10 men and 4 women. In Gambella town there were 5 men and 5 women. In Itang special wereda, there were 7 men and 3 women. Participants were asked to inform the seasonal availability of each type of fish, the gender division of labor involved in their capture fishery activities and forms of preparation of fish for marketing as well as home consumption.

\subsection{Method of Data Analysis}

Data were analysed using SPSS 20 and STATA version 14 software. The specific Statistical tools applied for the analyses were descriptive statistics using tables, mean, median and percentage while inferential methods such as chi-square were applied. Analysis of productive roles and work load, access to rural services and status of decision making was done using simple and illustrative tables. Data were analyzed using descriptive statistics such as mean, average, frequency and percentage. A qualitative approach using narrative techniques were used to analyze results of focus group discussions and a semi structured interview. 


\section{Results and Discussion}

The current section displays results of the analysis of the study. It further discusses findings from the investigation. It is divided into 4 major sub divisions. The first section focuses on displaying socio economic profile of the respondents, the second one stresses on the gender roles and workloads; while the third one shows access to selected rural services by men and women household heads. The fourth sub division focuses on focuses on reproductive gender roles.

\subsection{Socio economic status of the sample households}

In the rural community of Ethiopia, households make up the most important building blocks of the social system. They are the basic units especially for extension and resource allocation practices in Ethiopia (Etenesh, 2007). As indicated in the sampling section, socio economic data was collected among 52 households among whom 33 were male while 19 were female headed. The surveyed households were on average 32.6 years old. The Table 1 below also shows that the average age of male headed households is higher than that of the female headed households. Men were found to have a significantly higher level of education than women. The result is in line with the findings of Mahlet, 2005. The average amount of fish harvested per day has difference on male and female headed household as depicted in table 1 (10.5 kilogram per day for male headed household and 7.5 kilogram for female headed household ).The fish type Lates niloticus(Nile perch) demands a special skill of catching by hook. Thus, there is a big difference of harvest per day between male and female headed household. The table 1 below illustrates the detailed socio- economic profile of the respondents.

Table 1. Socio-economic profile and daily harvest of the respondents

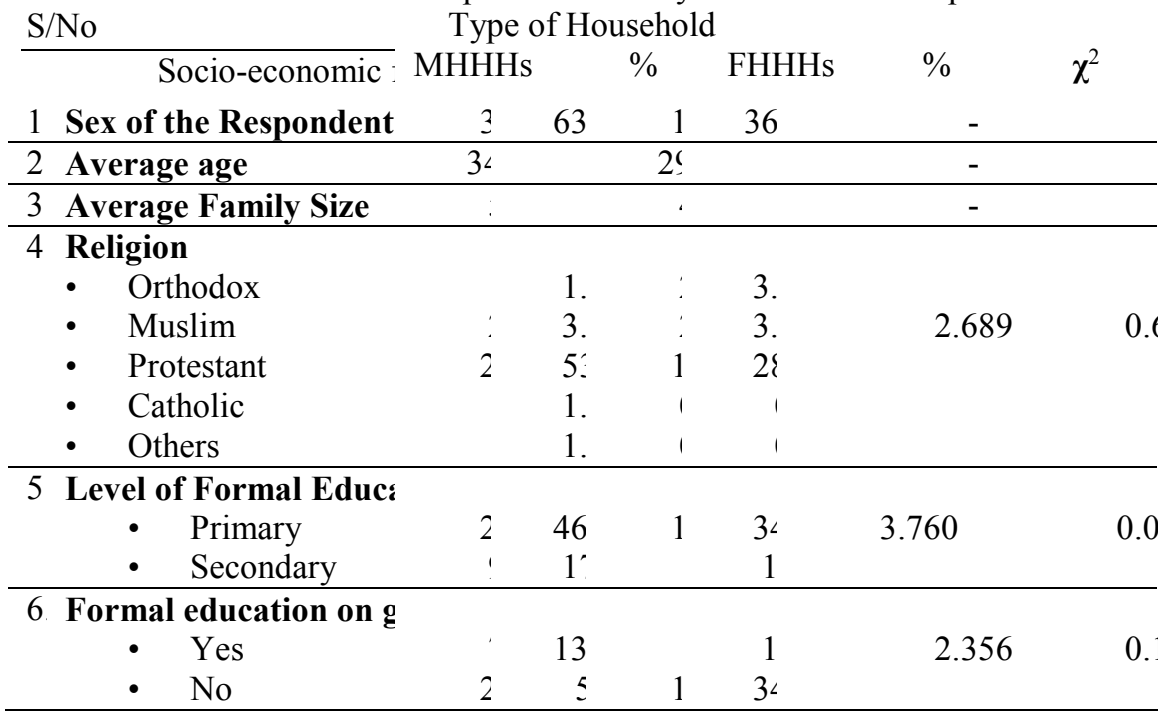

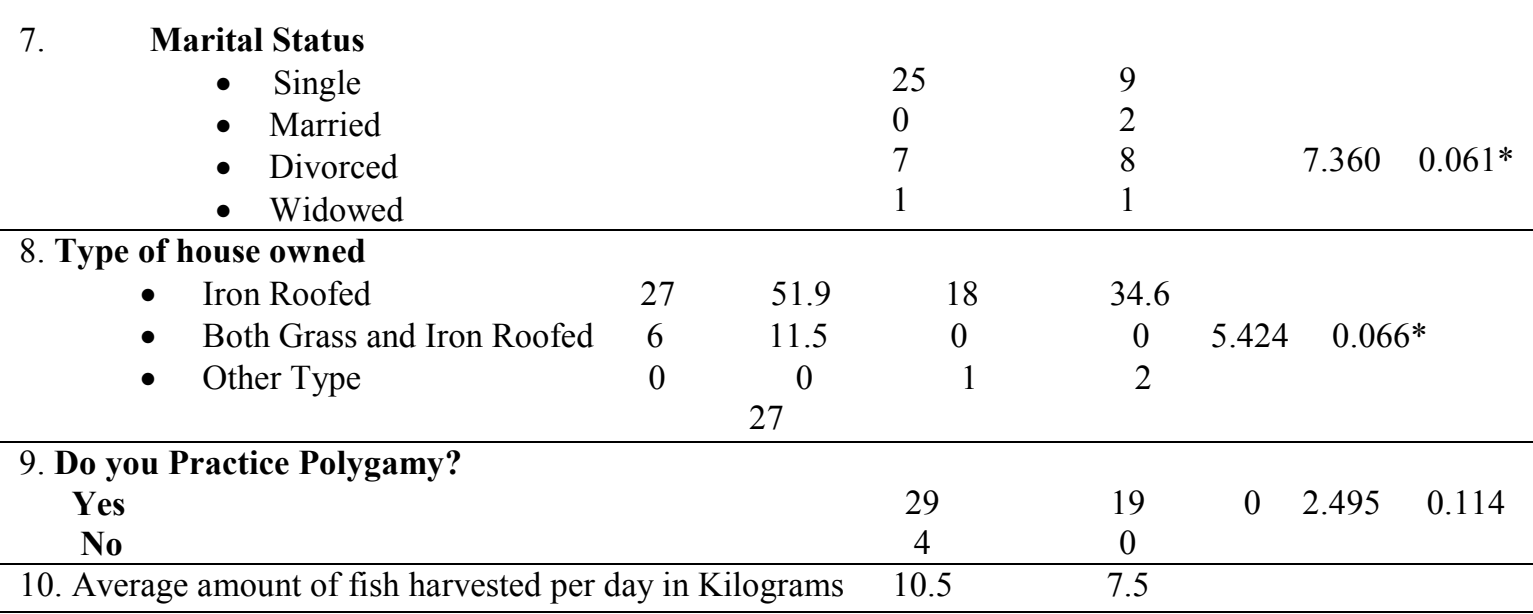


11.Dominant fish species harvested per day in kilograms

C. gariepinus (Catfish)

Lates niloticus(Nile perch)

B. docmac; B. bajad

O. niloticus ( Tilapia)

H. forskahlii (Tiger fish)

$\begin{array}{ccr}9.52 & 1 & 13.33 \\ 19.05 & 0 & 0 \\ 14.29 & 3 & 40 \\ 23.81 & 1 & 13.33 \\ 33.33 & 2.5 & 33.33\end{array}$

* "Significant at 10\% level of significance"

- Note: - FHHHs= Female headed households/women household heads/ and MHHHs= Male headed households/ Men household heads

Result of the above table indicates that there is a fairly significant association between gender and level of formal education, marital status and type of house owned by the respondent. Looking at the numerical result obtained from the analysis, one can judge the fact that men household heads are endowed with relatively "better houses", are single and have a better level of schooling, in terms of formal education. The result is in line with the finding of Mahlet, 2005.

\subsection{Productive Gender Roles and Work Load}

A productive gender role in fishery is defined as a set of different sub activities performed with respect to capture fishery. These sub activities are: doing the fishing activity which includes lining the gear and catching the fish or harvesting, collecting the catch, gutting, filleting transporting, cooking or selling the catch. The processing activities encompass gutting and filleting the harvested fish. The activity of fish catching is solely dominated by men. Still, there is an indication on the fact that most of the capture fishery related secondary activities are covered by women, demanding more of women specific technologies in the area. Several studies also assert that women are mostly engaged in fish processing, handling and preservation. Hence, the current finding is in line with studies conducted by FAO, 2013.

Table 2. Work Load in Productive Gender Roles of Capture Fishery

\begin{tabular}{lllll}
\hline S/No & Activity Performed by Men & Time Taken & Activity Performed by Women & Time Taken \\
\hline 1 & Fishing (Fish Catching) & $16 \mathrm{hrs}$ & Selling the Catch & $2 \mathrm{hr}$ \\
\hline 2 & Boat Maintenance & $2 \mathrm{hrs}$ & Filleting the Fish & $2 \mathrm{hrs}$ \\
\hline 3 & Gear Maintenance & $0.45 \mathrm{hr}$ & Cooking & $1.5 \mathrm{hrs}$ \\
\hline 4 & Gutting the Fish & $1 \mathrm{hr}$ & Gear Maintenance & $1 \mathrm{hr}$ \\
\hline 5 & Transporting & $1.5 \mathrm{hrs}$ & Collecting the catch & $4 \mathrm{hrs}$ \\
\hline 6 & Selling the Catch & $2 \mathrm{hrs}$ & & $\mathbf{1 0 . 5} \mathbf{h r s}$ \\
\hline
\end{tabular}

Source, Own Survey, 2009 EC

The above activity calendar on productive gender roles in table 2 indicated that unlike other agricultural activities when women's involvement is exhibited by time and labour intensive tasks, their involvement in majority of the activities in capture fishery is minimal. During our data collection, we observed that female head household use different means of labor for fishing activities. The primary source of labor is using youth as well as teenagers. Thus, daily catch in terms of volume as well as fish diversity is minimal. Meanwhile, the youth and women are very active in delivering their catch to market.

The labor division in male headed household is different from what we observed in female headed household. The head of the house mainly lead the fishing activity daily. Setting the net and hook are his major task. Youth are actively involved in regular checking the net and hook for harvest. In addition to this, they also actively involved in sorting fish based on the size, type of fish and other parameters. After sorting fish, youth also have a significant role in processing fish like filleting, gutting and transporting fish to the market. Women can also have different role in fishery. The lion share of them is preparing all fishing equipment on daily base by making an essential checkup of net maintenance; counting hook for daily consumption, as well as preparing breakfast for their husband and youth. In addition to these, women have a significant role on post harvest handling of fish in study area. They usually involved in processing the fish and exposed it to sun for drying. This process needs a very high endurance and time which women can able adorably. Women also involved in fish marketing as activity occasionally for fulfilling their home need. 
Table 3. Work load of women \& youth in Male headed household, productive gender roles of capture fishery

\begin{tabular}{|c|c|c|c|c|}
\hline S/No Activity Performed by women & Time Take & Activity Performed by youth & & Time Take \\
\hline 1 Selling the Catch & 4 hrs & Selling the Catch & & $3 \mathrm{hrs}$ \\
\hline 2 Filleting the Fish & $3 \mathrm{hrs}$ & Filleting the Fish & & $4 \mathrm{hrs}$ \\
\hline 3 Cooking & $2 \mathrm{hrs}$ & Gear Maintenance & & $1.5 \mathrm{hrs}$ \\
\hline 4 Gutting the Fish & $1 \mathrm{hr}$ & Collecting the catch & & $3 \mathrm{hrs}$ \\
\hline 5 Collecting the catch & $1 \mathrm{hr}$ & Sorting the catch by type $\&$ size & 0.7 & $1.5 \mathrm{hrs}$ \\
\hline $6 \quad$ Sorting the catch by type \& size & $0.5 \mathrm{hr}$ & & & \\
\hline Total Time Spent & $11.5 \mathrm{hrs}$ & & & 13 hrs \\
\hline
\end{tabular}

Source, Own Survey, 2009 EC

The activities performed by family members of male headed household (Table 3) vary from female headed household. In male headed household, women can do a lot of activities which majorly took their time selling the catch demanding 4 hours. The activity of filleting the catch can took 3 hours followed by cooking and gutting took 2 and 1 hour respectively. The share of youth in male headed household was very vital. In dominant case, they involved in filleting the fish which need 4 hours per catching effort. They have also active role in selling and collecting the catch which both demand 3 hours. In capture fishery particularly in Gambella region, gear is mostly used catching equipment. This equipment is highly reliable for attack of crocodile and other big fish. Thus, fishers are very much active in checking the statues of the gear daily and this activity is dominantly undertaken by youth. The activity of gear maintenance usually demand 1.5 hours daily after collecting the catch. The other activity daily performed was sorting the catch by type and size of fish harvested. This activity is done immediately after removing the fish from the water. All the fish type is not directed to the market. Thus youth frequently sort it for home consumption and as catching pieces of meat entangled in hooks. The size of fish frequently offered to the market varies place to place. In Gambella town market (the largest fish market in the region) fishers are expected to bring fish having a minimum size of 350 grams each. This scenario is different in Abobo market areas (the second largest fish market place) which fishers expected more size of fish daily.

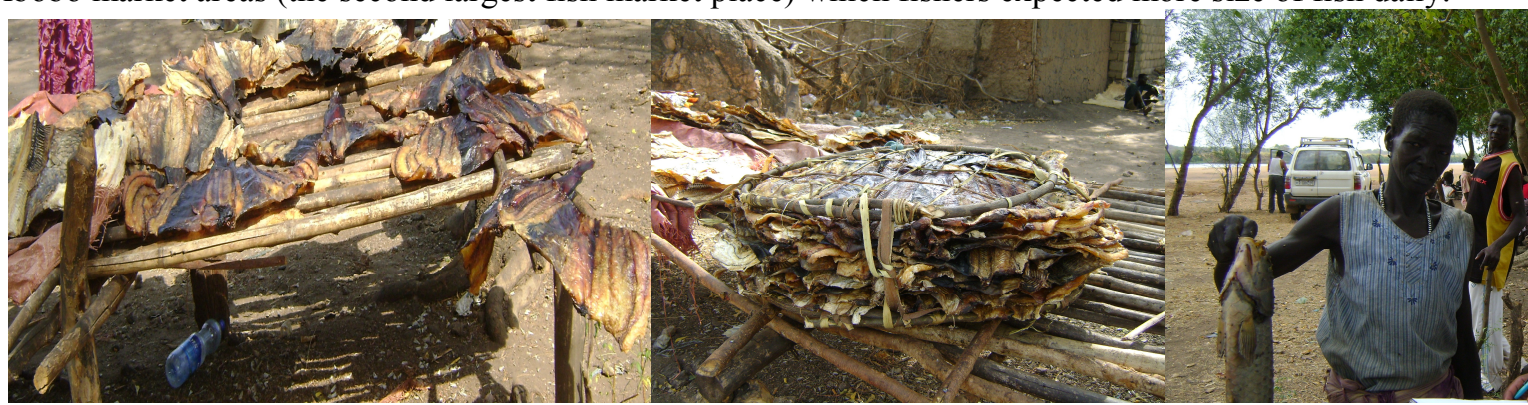

Fig.1 . Cultural sun drying method, Packaging and women participating on selling whole fish in Gambela town

Table 4. Productive Gender roles in Capture fishery of Gambela

\begin{tabular}{|c|c|c|c|c|c|c|}
\hline \multirow[b]{3}{*}{ Variable } & \multicolumn{4}{|c|}{ Sex } & \multirow[b]{3}{*}{$\chi^{2}$} & \multirow[b]{3}{*}{ Sig } \\
\hline & \multicolumn{2}{|c|}{ Men } & \multicolumn{2}{|c|}{ Women } & & \\
\hline & Yes & No & Yes & No & & \\
\hline Doing the Fishing Activity & 33 & 0 & 0 & 19 & $52.00 * * *$ & 0.000 \\
\hline Collecting the Catch & 9 & 24 & 12 & 7 & $6.449 * *$ & 0.011 \\
\hline Processing the Catch & 12 & 21 & 16 & 3 & $11.107 * * *$ & 0.001 \\
\hline Cooking the Catch & - & - & 19 & 0 & - & - \\
\hline Selling the Catch & 12 & 21 & 14 & 5 & $6.718 * *$ & 0.010 \\
\hline Decision on Selling the Catch & 16 & 17 & 6 & 13 & 1.412 & 0.235 \\
\hline \multicolumn{7}{|c|}{$\begin{array}{l}\text { The above chi square results from table } 3 \text { indicate that it is the duty of men to do the actual fishing activity } \\
\text { while women are involved in collecting, processing, cooking and selling the catch. Though men have quite a } \\
\text { better decision making role in selling or not selling the catch, the decision has somehow landed on both parties } \\
\text { (men and women). Hence, the table above shows the presence of non significant difference between men and } \\
\text { women household heads in making decision about selling or not selling the catch. It implies that there is a shared } \\
\text { decision making in selling or not selling the catch at household level, which is normally recommended. }\end{array}$} \\
\hline
\end{tabular}

\subsection{Community Roles}

Results of a focused group discussion conducted with prime members of the community indicated the presence of fairly the same level of community participation between the men and women household heads. This is also 
depicted by the presence of insignificant relationship as shown in the table below (Table 4): In fulfilling community roles, women fisher households use women's groups, while men were found to be inclined towards non membership in any of the farmer associations in the study area. Hence, there is an association between gender and membership in an association. Regarding membership in any of the community based organizations or other, the current finding is in line with that of Mahlet, 2005.

Table 4. Community roles

\begin{tabular}{|c|c|c|c|c|c|c|}
\hline \multirow{3}{*}{ Variable } & \multicolumn{4}{|c|}{ Sex of the respondent } & \multirow{3}{*}{$\chi^{2}$} & \multirow{3}{*}{ Sig } \\
\hline & \multicolumn{2}{|c|}{ Men } & \multicolumn{2}{|c|}{ Women } & & \\
\hline & Yes & No & Yes & No & & \\
\hline $\begin{array}{l}\text { Are you a member of any } \\
\text { association? }\end{array}$ & 16 & 17 & 13 & 6 & 1.943 & 0.163 \\
\hline $\begin{array}{cl}\text { Are You a member of: } \\
\text { - } & \text { Women's Group } \\
& \text { Non Member } \\
& \text { (women } \\
& \text { association ) } \\
\end{array}$ & $\begin{array}{l}- \\
17\end{array}$ & - & $\begin{array}{c}10 \\
6\end{array}$ & 3 & $43.868 * * *$ & 0.000 \\
\hline
\end{tabular}

\section{Focus group Discussion}

As indicated in methodology part, fishers were aware about the issue of gender on production and marketing of fish in the study area. The gaps were categorized on marketing and production constraints. There was inconsistency in availability of modern boat and distance of primary fish market places. Women are not usually use modern boat for fishing rather using hooks regularly.

Table 5. Gap analysis and research implication

\begin{tabular}{|c|c|c|c|c|}
\hline \multirow{2}{*}{ Cluster } & \multicolumn{3}{|c|}{ Evaluation } & \multirow{2}{*}{ Gap } \\
\hline & Quality & Size & Consistency & \\
\hline 1. Lack fish modern boat & High & Large & inconsistent & $\begin{array}{c}\text { There was a great difference male and } \\
\text { female participant on the importance } \\
\text { of having the item against daily } \\
\text { catches of fish. }\end{array}$ \\
\hline 2. Lack of modern net & High & Large & Consistent & \\
\hline $\begin{array}{ll}\text { 3. } & \text { Expensiveness of } \\
\text { fishing material } & \end{array}$ & High & Large & Consistent & \\
\hline \multicolumn{5}{|l|}{ Marketing Constraints } \\
\hline $\begin{array}{l}\text { 1. Long Distance of } \\
\text { primary fish market } \\
\text { places }\end{array}$ & Moderate & Medium & inconsistent & $\begin{array}{l}\text { Women were disagreed about the } \\
\text { distance of market places due to high } \\
\text { pressure of household duties. }\end{array}$ \\
\hline 2. Low price of fish & High & Large & Consistent & \\
\hline $\begin{array}{l}\text { 3. Low value adding } \\
\text { facilities }\end{array}$ & High & Large & Consistent & \\
\hline
\end{tabular}

\subsection{Reproductive Gender Roles}

The reproductive gender roles are not quantitatively analyzed. But, results of the focused group discussion conducted with the sample households indicated that the household home care takers are women including child rearing and kitchen related cooking, cleaning and other activities.

\subsection{Access to Selected Rural Services}

In accessing significant rural services such as extension, credit and training, no significant difference was found between men and women led households for the latter two. This is because, when fisher farmers are invited for training, it is irrespective of their sex status and not discriminated in that regard. This was also confirmed by the focused group discussion conducted among the selected households. The extension service delivery in capture fishery is male biased. This was because contents of the service are targeted towards more commonly known and customary activities with the men in mind. These activities are mostly related to doing the fishing activity or fish catching itself. The male dominated perception of who normally fishes also limited extension service providers from approaching women in female headed households. Hence, a significant relationship was found between gender and access to extension services (see table 4 below). The same was confirmed by a group discussion 
conducted with the participants. Result of the current study also aligns with the findings of Mahlet, 2005 and FAO, 2011.

Table 6. Access to Rural Services among men and women

\begin{tabular}{lcccccc}
\hline & \multicolumn{2}{c}{ Men } & \multicolumn{3}{c}{ Women } & \multicolumn{2}{c}{ Nex } & \multicolumn{2}{c}{ Sig } \\
Variable & Yes & No & Yes & No & $\mathbf{X}^{\mathbf{2}}$ & Sig \\
\hline Access to credit services & 0 & 0 & 0 & 0 & - & - \\
\hline Access to extension services & 13 & 20 & 3 & 16 & $3.154^{*}$ & 0.076 \\
\hline Access to training services & 10 & 23 & 3 & 16 & 1.355 & 0.244 \\
\hline
\end{tabular}

* Significant at $10 \%$ level of significance

\section{CONCLUSION AND RECOMMENDATION}

\subsection{CONCLUSION}

Average age of respondents was $\mathbf{3 2 . 6}$ years. Average family size $\mathbf{5}$ and $\mathbf{4}$ for MHHHs \& FHHHs respectively.A total of $10.5 \& 7.5$ Kilograms of fish were the average amount harvested per day by MHHHs \& FHHHs respectively. There was a variation in daily harvest of fish by its type. The dominant fish type that can harvested daily was H. forskahlii (Tiger fish) having an average catch of 3.5 and 2.5 kilograms per day by MHHHs\& FHHHs respectively.

There was a variation in time spent for different activities on fishing community. The major activity, fishing (Fish Catching) demands $16 \mathrm{hrs}$ and selling the Catch $2 \mathrm{hrs}$ for MHHHs. The major activities undertaken by FHHHs were collecting the catch 4 hrs and Filleting the Fish 2 hrs. The primary source of labor or FHHHs was using youth as well as teenagers. This lead relatively lower level of harvest per day as compared to MHHHs.In male headed household, women can do a lot of activities which majorly took their time selling the catch demanding 4 hours. The activity of filleting the catch can took 3 hours followed by cooking and gutting took 2 and 1 hour respectively. The share of youth in male headed household was very vital. In dominant case, they involved in filleting the fish which need 4 hours per catching effort. There was a significant difference on fishing activity(harvesting), extension services, collecting \& processing the catch among MHHHs and FHHHs.

\subsection{RECOMMENDATION}

$\checkmark \quad$ Daily fish catch of women headed household should be increased by offering improved fishing equipments.

$\checkmark \quad$ Value adding facilities should be given due attention in to boost up returns from fishery.

$\checkmark$ Constant nearby fish market place with full facility should be arranged in the areas where the resources are available.

$\checkmark$ Credit, extension and training services should be given a special concern for being better off the fishery community.

$\checkmark$ Fishing equipments and other aid materials are very scarce. Thus, respected organizations should give a priority for alleviating the problem.

\section{REFERENCES}

Bennett, E., Neiland, A., Anang, E., Bannerman, P., Rahman, A., Huq, A., Bhuyia, S., Day, M. Fulford-Gardiner, M. and W. Clerveaux. 2001. "Towards a better understanding of conflict management in tropical fisheries: evidence from Ghana, Bangladesh and the Caribbean".Marine Policy 25:5: 365-76.

Candida March, Ines Smyth and Maitrayee Mukhopadhyay, 1999. A Guide to Gender Analysis Frameworks: An Oxfam (Edn). London.

Choo, P.S.,Nowak, B.S., Kusakabe, K. and M.J. Williams. 2008. "Guest editorial: Gender and fisheries". Development 51:2: 176-79.

CSA, 2013: Population projection of Ethiopia for all regions at woreda level from 2014-2017. Addis Ababa, Ethiopia.

Etenesh Melese, 2007. Impact of Development Induced Displacement in Female Headed Households in Inner City Slum Areas of Addis Ababa: The Case of Sheraton Addis Expansion Project. An M.Sc. Thesis Presented to the School of Graduate Studies of Addis Ababa University. 106p.

FAO,2003. The state of world fisheries and aquaculture. Fisheries and Aquaculture Department of the Food and Agriculture Organization of the United Nations. Rome

FAO. 2006. Gender policies for responsible fisheries. Rome: FAO.

FAO, 2011. The role of women in agriculture: Closing the gender gap for development.

FAO (2011) The State of Food and Agriculture 2010-11: Women in agriculture, closing the gender gap for development, Rome, Italy: Food and Agriculture Organization / www.fao.org/docrep/013/i2050e/i2050e. pdf

FAO, World Fish Center and World Bank, 2008. Small-scale capture fisheries: a global overview with emphasis 
on developing countries. Big Numbers Project Report: Food and Agriculture Organization of the United Nations, World Fish Center and World Bank FAO Rome; WFC, Penang; World Bank, Washington D.C, 64 pp.

FAO, 2016. The State of world fish and aquaculture: A project Report: Food and Agriculture Organization of the United Nations. Washington D.C.

Fetenu, B. 1997. The gender dimension in development project: concepts, approach and framework for gender analysis, Dry Land Husbandry Project (DHP) publication series.

Harrison, E. 2001. Gender; rights and poverty issues: lessons for the sector. Background paper for DFID/FGRP3/ARP Workshop on practical strategies for poverty targeted research; 7-11 November. Overseas Development Institute, $23 \mathrm{pp}$.

Hazel, R. and Sally, B., 2000. Gender and Development: Concepts and Definitions. A Report. University of Sussex, UK.

ICSF. 2002. Report of the study on the problems and prospects of artisanal fish trade in Africa. Chennai: ICSF.

Kusakabe. K. Sereyvath, P.,Suntornratana, U and N. Sriputinibondh. 2006. Women in fish border trade: "The case of fish trade between Cambodia and Thailand". In Choo, P.S., Hall, S.J and M.J. Williams (Eds.) Global Symposium on Gender and Fisheries, p. 91- 102. Seventh Asian fisheries Forum, 1-2 December 2004, Penang, Malaysia. Penang: WorldFish Center.

Mahlet Abitew, 2007. Gender Analysis in Agriculture: Implication for Agricultural Extension in Alemaya Woreda, Ethiopia. An M.Sc. Thesis Presented to the School of Graduate Studies of Addis Ababa University.

Nakato, M. 2005. "Women and globalization in Ugandan fisheries". In Frangoudes and Pascual-

Fernandez (Eds.) Women in fisheries and aquaculture: Lessons from the past, current actions and ambitions for the future, p.151-158. Proceedings of the International Conference AKTEA,Santiago de Compostela, Spain, November 2004. Tenerife: Asociacion Canaria de Antropologia.

Okali, C. and K. Holvoet. 2007. Negotiating changes within fisheries development. Sustainable Fisheries Livelihoods Programme: FAO/DFID.

Ostergaard, L. 1997. Gender and Development: A practical guide. Routledge, London.

Overa, R. 1993. "Wives and traders: Women's careers in Ghanian canoe fisheries." MAST 6(1/2):110-135.

Porter,M. 2006. Gender and fisheries: A global perspective. Paper presented at "Global coasts: Gender, fisheries and contemporary issues, International Symposium”, University of Tromso, Norway, June 2006.

Vales, E. 2005. "A participacao da mulher na pesca em Mozambique". In Frangoudes and Pascual- Fernandez (Eds.) Women in fisheries and aquaculture: Lessons from the past, current actionsand ambitions for the future, p.199-208. Proceedings of the International Conference AKTEA,Santiago de Compostela, Spain, November 2004. Tenerife: Asociacion Canaria deAntropologia.

Vunisea, A. 1997. "Women's fishing participation in Fiji”. SPC Women in Fisheries Bulletin 1:10-13.Williams, M.J. 2008. "Why look at fisheries through a gender lens?" Development 51:2: 180-85.

Walker, B. L. E. 2002. "Engendering Ghana's seascape: Fanti fish traders and marine property in colonial history". Society and Natural Resources 15: 389-407.

Williams, M.J., Choo, P.S., and Hall, S.J., 2004. Global Symposium on Gender and Fisheries. P 1. Proceedings of the Global Symposium on Gender and Fisheries. Penang, Malaysia, 1-2 December 2004, World Fish Center.

World Bank, 2009. Gender in Agriculture: Sourcebook. A World bank (edn). Washington DC. 